\title{
Supervisi Pendidikan
}

\author{
Yuni Kartika Sari \\ Universitas Negeri Padang \\ Indonesia \\ E-mail : yunikartikasari446@gmail.com
}

\begin{abstract}
Abstrak-As the teris curriculum develops, these developments often lead to changes in the structure and function of the curriculum. The implementation of the curriculum requires continual adjustments to the real situation on the ground. For this reason, teachers must always try to develop their creativity so that educational efforts based on the curriculum can be carried out properly. Employee development is always a continual effort in an organization. For this reason, it is necessary to supervise education, to improve the performance of teachers and employees in the learning process.
\end{abstract}

Keywords-(Supervisi Pendidikan, supervision of teachers and school principals.)

\section{PENDAhUlUAN}

Supervisi pendidikan adalah hal yang sangat penting dilakukan untuk meningkatkan mutu pendidikan. Mutu pendidikan sangat berkaitan erat dengan keprofesionalan guru dalam menghadapi permasalahan-permasalahan yang ada didunia pendidikan baik pada masa saat ini atau masa yang akan datang. Berdasarkan hal tersebut pendidikan merupakan faktor yang penting karena pendidikan salah satu penentu mutu SDM (Sumber Daya Manusia), dimana manusia dapat membina kepribadiannya dengan jalan mengembangkan potensipotensi yang dimiliki sesuai dengan nilai-nilai yang ada di dalam masyarakat. Dalam usaha meningkatkan kualitas sumber daya pendidikan, guru merupakan komponen sumber daya manusia yang harus dibina dan dikembangkan terus menerus. Guru adalah tugasnya yang terkait dengan upaya mencerdaskan kehidupan bangsa dalam semua aspeknya, baik spiritual dan emosional, intelektual, fisikal, maupun aspek lainnya (Suparlan, 2005: 12).

Potensi sumber daya guru itu perlu terus bertumbuh dan berkembang agar dapat melakukan fungsinya secara potensial. Selain itu pengaruh perubahan yang serba cepat mendorong guru-guru untuk terus menerus belajar menyesuaikan diri dengan ilmu pengetahuan dan teknologi serta mobilitas masyarakat. Guru membutuhkan bantuan dari sesama rekan guru yang memiliki kelebihan atau guru yang sudah berpengalaman untuk saling bertukar ilmu pengetahuan dalam meningkatkan potensi peserta didik. Guru juga membutuhkan bantuan kepala sekolah sebagai pembina pembimbing guru agar bekerja dengan benar dalam proses pembelajaran siswanya. Oleh karena itu, dalam suatu lembaga pendidikan perlu adanya pelaksanaan supervisi."Supervision also can be interpreted as a two ways interactional process that requires both the student and the supervisor to consciously engage each other within the spirit of professionalism, respect, collegiality and open-mindedness", Abiddin (2011: 207)

Dalam perkembangannya, pengawas satuan pendidikan lebih diarahkan untuk memiliki serta memahami bahkan dituntut untuk dapat mengamalkan apa yang tertuang dalam peraturan menteri tentang kepengawasan. Tuntutan tersebut salah satunya tentang kompetensi dalam memahami metode dan teknik dalam supervisi. Seorang supervisor adalah orang yang profesional ketika menjalankan tugasnya, ia bertindak atas dasar kaidah-kaidah ilmiah untuk meningkatkan mutu pendidikan.

Guru adalah salah satu komponen sumber daya pendidikan memerlukan pelayanan supervisi. Pentingnya bantuan supervisi pendidikan terhadap guru berakar mendalam dalam kehidupan masyarakat. Untuk menjalankan supervisi diperlukan kelebihan yang dapat melihat dengan tajam terhadap permasalahan dalam peningkatan mutu pendidikan, menggunakan kepekaan untuk memahaminya dan tidak hanya sekedar menggunakan penglihatan mata biasa, sebab yang diamatinya bukan masalah kongkrit yang tampak, melainkan memerlukan kepekaan batin.

Seorang supervisor membina peningkatan mutu akademik yang berhubungan dengan usaha-usaha mennciptakan kondisi belajar yang lebih baik berupa aspek akademis, bukan masalah fisik material semata. Ketika supervisi dihadapkan pada kinerja dan pengawasan mutu pendidikan, tentu memiliki misi yang berbeda dengan supervisi oleh kepala sekolah. Hal ini bertujuan untuk memberikan pelayanan kepada kepala sekolah dalam mengembangkan mutu kelembagaan pendidikan dan memfasilitasi kepala sekolah agar dapat melakukan pengelolaan kelembagaan secara efektif dan efisien.

\section{Metode Penelitian}

Artikel ilmiah seharusnya disusun dengan metode dan langkah-langkah yang sistematis. Pada artikel ini, penulis menggunakan metode mengumpulkan bahan dan materi dari buku, jurnal, artikel, dan sumber lain yang berkaitan dengan Supervisi Pendidikan. Metode literatur yang berhubungan dengan topik yang diminati dapat membantu mempermudah dalam merumuskan masalah penelitian, metode ini disebut juga dengan metode SLR (Systematic Literature Review). Setelah bahan kajian dan materi dikumpulkan, kemudian diteliti. Penulis nantinya menyimpulkan pengetahuan yang penulis dapatkan dari materi tersebut. Metode literatur ini bertujuan untuk membantu menemukan wawasan, kebenaran dan juga penyelesaian dari masalah yang dihadapi. Sebagai petunjuk yang terbukti kebenarannya sebaiknya menggunakan 
buku-buku dengan tanngal hak cipta baru. Semakin baru sebuah buku ditulis maka semakin cocok dengan zaman dari materi yang akan ditelaah/dipelajari.

\section{KAJIAN TEORI DAN PEMBAHASAN}

\section{A. Konsep dasar supervisi pendidikan (pengertian, rasional, tujuan dan fungsi)}

Kata supervisi berasal dari bahasa Inggris yaitu supervision, terdiri atas dua kata, yaitu super dan vision yang mengandung pengertian melihat dengan sangat teliti pekerjaan secara keseluruhan. Orang yang melakukan supervisi yang disebut supervisor. Suharsimi menjelaskan, bahwa supervisi terdiri dari dua kata "super" dan "vision" yang berarti "melihat" maka secara keseluruhan supervisi diartikan sebagai melihat dari atas. Dengan pengertian itulah supervisi dikatakan sebagai kegiatan yang dilakukan oleh kepala sekolah sebagai pejabat yang berkedudukan di atas lebih tinggi dari guru untuk melihat dengan teliti pekerjaan secara keseluruhan atau mengawasi pekerjaan guru.

Pengertian supervisi dalam kaitannya dengan pendidikan adalah pembinaan guru. Konsep supervisi tradisional menganggap supervisi sebagai inspeksi. Hal inilah yang menyebabkan guru merasa takut dan tidak bebas melakukan tugasnya serta merasa terancam dan merasa takut untuk bertemu dengan supervisor, bahkan supervisor dianggap tidak memberikan dorongan bagi kemajuan guru. Sikap tersebut dipengaruhi oleh pemahaman tentang supervisi secara tradisional, artinya supervisor dipahami sebagai pengawasan dalam pengertian mencaricari kesalahan dan menemukan kesalahan untuk diperbaiki yang pada gilirannya mempengaruhi penilaian terhadap guru.

Dalam pengertian lain, supervisi merupakan peningkatan makna dari inspeksi yang berkonotasi mencaricari kesalahan, jelaslah bahwa kesan seperti itu sangat kurang tepat dan tidak sesuai lagi dengan zaman reformasi seperti sekarang ini. Mengenai pengertian supervisi pendidikan, Ali Imron menjelaskan bahwa supervisi pendidikan adalah serangkaian bantuan kepada guru, terutama bantuan yang berwujud layanan profesional untuk meningkatkan proses belajar mengajar. Selanjutnya Sahertian berpendapat, bahwa supervisi pendidikan adalah sebagai pemberian pelayanan dan bantuan guna meningkatkan kualitas pendidikan. Ada tiga unsur penting yang harus diperhatikan tentang supervisi pendidikan, yaitu:

1. Unsur proses pengarahan, bantuan atau pertolongan dari pihak atasan atau pihak yang lebih memahami.

2. Unsur guru-guru dan personalia sekolah lainnya yang berhubungan langsung dengan belajar mengajar para siswa sebagai pihak yang diberikan pertolongan.

3. Unsur proses belajar mengajar atau situasi belajar mengajar sebagai objek yang diperbaiki.

Supervisi merupakan suatu aktivitas pembinaan yang direncanakan untuk membantu para guru di madrasah dalam melakukan pekerjaan secara aktif. Supervisi bukanlah kegiatan sesaat seperti inspeksi, tetapi merupakan kegiatan yang continue dan berkesinambungan sehingga guru selalu berkembang dalam mengerjakan tugas dan mampu memecahkan berbagai masalah pendidikan dan pengajaran secara afekitf dan efisien. Secara implisit definisi supervisi memiliki wawasan dan pandangan baru tentang supervisi yang mengandung ide-ide pokok, seperti menggalakkan pertumbuhan profesional guru, mengembangkan kepemimpinan demokratis, melepaskan energi, dan memecahkan berbagai masalah yang berkaitan dengan efekitivitas proses belajar mengajar.

Pada hakekatnya supervisi mengandung beberapa kegiatan pokok, yaitu pembinaan yang continue, pengembangan kemampuan profesional personil, perbaikan situasi belajar mengajar, dengan sasaran akhir pencapaian tujuan pendidikan dan pertumbuhan pribadi peserta didik. Dengan kata lain, dalam supervisi ada proses pelayanan untuk membantu atau membina guru-guru, pembinaan ini menyebabkan perbaikan atau peningkatan kemampuan kemudian ditransfer kedalam perilaku mengajar sehingga tercipta situasi belajar mengajar yang lebih baik, yang akhirnya juga meningkatkan pertumbuhan peserta didik. Supervisi merupakan proses bantuan bagi guru dalam mengembangkan kemampuannya yang meliputi pengetahuan, keterampilan mengajar dan komitmen atau motivasi guru. Jadi tujuan supervisi berkenaan dengan aspek kognitif, psikomotor dan afektif adalah membantu memperbaiki dan meningkatkan pengelolaan sekolah sehingga tercapai kondisi kegiatan belajar mengajar yang sebaik-baiknya.

Tujuan supervisi menurut Hariwung adalah sebagai pengendalian kualitas, pengembangan profesional dan untuk memotivasi guru. Supervisi sebagai pengendalian kualitas artinya, kepala sekolah sebagai supervisor bertanggung jawab memonitor proses belajar mengajar di sekolah dengan cara berkunjung ke kelas, berkonsultasi dengan guru yang dapat diharapkan pendidikan mampu menilai dan mengetahui kemampuan siswa. Supervisi yang baik adalah supervisi yang mampu merefleksikan multi tujuan tersebut. Supervisi tidak berhasil jika hanya memperhatikan salah satu tujuan tertentu dengan mengesampingkan tujuan yang lain. Jadi dengan demikian dapat dipahami, bahwa tujuan supervisi pendidikan adalah perbaikan dan perkembangan proses belajar mengajar secara total, ini berarti tujuan supervisi tidak hanya untuk memperbaiki mutu mengajar guru, tapi juga membina pertumbuhan profesi guru dalam arti luas, termasuk di dalamnya pengadaan fasilitas-fasilitas, pelayanan kepemimpinan dan pembinaan hubungan yang baik kepada semua pihak yang terkait.

Adapun fungsi utama supervisi pendidikan ditujukan pada perbaikan dan peningkatan proses belajar mengajar guru di sekolah. Sehubungan dengan hal ini, menurut pendapat Malik supervisi terhadap kinerja guru dalam proses belajar mengajar memiliki tiga fungsi utama yaitu:

1. Supervisi kurikulum untuk menjamin penyampaian kurikulum dengan tepat.

2. Perbaikan proses pembelajaran dengan membantu guru merencanakan program akademis. 
3. Pengembangan profesi dalam melaksanakan program pengajaran.

Menurut Swearingen dalam Piet A Sahertian (2010: 21), terdapat 8 hal yang menjadi fungsi supervisi yakni sebagai berikut:

1. Mengkoordinasikan semua usaha sekolah

2. Memperlengkapi kepemimpinan sekolah

3. Memperluas pengalaman guru-guru

4. Menstimulasi usaha-usaha yang kreatif

5. Memberi fasilitas dan penilaian yang terus menerus

6. Menganalisis situasi belajar mengajar

7. Memberikan pengetahuan dan keterampilan kepada setiap anggota staf

8. Mengintegrasikan tujuan pendidikan dan membantu meningkatkan mengajar guru-guru.

Sesuai dengan fungsinya, supervisi harus bisa mengkoordinasikan semua usaha-usaha yang ada di lingkungan sekolah yang bisa mencakup usaha setiap guru dalam mengaktualisasikan diri dan ikut memperbaiki kegiatan-kegiatan sekolah. Dengan demikian perlu dikoordinasikan secara terarah agar benarbenar dapat mendukung kelancaran program secara keseluruhan. Supervisi ditujukan untuk menghasilkan perubahan manusia kearah yang dikehendaki, kemudian kegiatan supervisi harus disusun dalam suatu program yang merupakan kesatuan yang direncanakan dengan teliti dan ditujukan kepada perbaikan pembelajaran.

Menurut Oteng Sutisna 21.(1987), menjelaskan bahwa supervisi berfungsi sebagai:

\section{Supervisi sebagai pengerakan perubahan}

Kegiatan proses belajar mengajar di madrasah atau sekolah merupakan suatu usaha yang ditujukan untuk menghasilkan prubahan prilaku manusia, baik secara individu maupun kelompok. Sebagaimana disebutkan dalam Undangundang Sistem Pendidikan Nasional, Nomor.2 tahun 1989 pasal, 3."Pendidikan Nasional berfungsi untuk mengembangkan kemampuan serta meningkatkan mutu kehidupan dan martabat manusia Indonesia dalam rangka usaha mewujudkan tujuan Nasional."Sistem pendidikan nasional pada hakikatnya, bahwa pendidikan merupakan kegiatan untuk menghasilkan suatu perubahan sesuai dengan tujuan yang hendak dicapai. Dengan demikian madrasah atau sekolah merupakan lembaga pendidikan sebagai wadah peserta didik tumbuh, berkembang dan berubah menjadi pribadi-pribadi yang beriman dan bertaqwa kepada Allah SWT, berbudi pekerti luhur, memiliki pengetahuan dan ketrampilan, sehat jasmani dan rohani, memiliki keperibadian yang mapan, mandiri serta rasa tanggung jawab kemasyarakatan dan punya rasa kebangsaan yang tinggi. Perkembangan ilmu pengetahuan dan teknologi yang sangat pesat, mendorong para supervisi pendidikan mejalankan fungsi yang stratergis dalam mengontrol prilaku para guru sebagai suatu usaha peningkatan kualitas hasil belajar. Adapun yang dimaksud dengan perubahan ialah, berusaha untuk meningkat kemampuan profesionalisme guru melalui berbagai cara, antara lain melalui penataran, seminar, simposium, bimbingan, diskusi ilmiah, pelatihan pengajaran dan lain sebagainya. Cara yang tersebut diharapkan profesionalisme guru dapat terus ditingkatkan dari hari kehari.

\section{Supervisi Pendidikan Sebagai Program Pelayanan} Kemajuan Pengajaran.

Supervisi pendidikan yang efektif, berusaha memperbaiki dan memajukan pengajaran, Oleh karena itu supervisi pendidikan harus di dasarkan kepada perencanaan yang mantap. Perencanaan tersebut harus sistematis, rasionalis dan dapat dilaksanakan secara efektif dan efisien. Seorang guru memegang posisi penting dalam proses belajar mengajar dan sebagai kunci dalam pelaksanaan dan keberhasilan dalam proses belajar mengajar di Madrasah atau Sekolah, Oleh karenanya penyusunpenan program pelayanan supervisi pendidikan lebih mengutamkan pada pembinaan dan peningkatan kemampuan profesional guru.

3. Supervisi Sebagai Ketrampilan Hubungan Manusia. Supervisi pendidikan lebih menitik beratkan pada unsur manusianya, karena penguasaan pengetahuan, teknologi dan keterampilan teknis oleh para personil belum merupakan jaminan atau faktor keberhasilan proses belajar mengajar seorang guru, akan tetapi faktor sikap dari personil sangat mempengaruhi produktifitas kinerja seorang tenaga pendidik dalam proses belajar mengajar. Sikap ini dapat dibentuk melalui hubungan manusia secara timbale balik antara seorang guru dengan kepala sekolah dan supervisor serta temen sejawat yang ada di sekelilingnya. Melalui hubungan baik tersebut, berbagai masalah yang di alami dan dihadapi guru dalam pelaksanaan proses belajar mengajar dapat direkam oleh pengawas (supervisor) dan kepala sekolah sebagai pelaksana supervisi pendidikan. Dengan mengetahui masaalah yang dihadapi oleh para guru, baik yang dapat terpantau maupun tidak, terhadap prilaku, para guru, maka supervisor atau kepala sekolah dapat memberikan bantuan, bimbingan profesional baik secara individual maupun kelompok, yang merupakan suatu usaha membantu para guru dalam memecahkan berbagai masalah yang sedang dihadapi oleh seorang guru di Madrasah atau sekolah.

\section{Supervisi Sebagai Kepemimpinan Kooperatif.}

Pelaksanaan supervisi pendidikan sebagai kepemimpinan kooperatif berazaskan demokrasi yang melibatkan personelpersonel yang terkait dalam pembinaan tersebut. Supervisi pendidikan mempunyai peranan untuk mengembangkan kepemimpinan terhadap guru-guru. Caracara yang ditempuh dalam pengembangan kepemimpinan

\section{B. Ruang lingkup supervisi pendidikan}

Berkaitan dengan ruang lingkup supervisi akademik, Permendiknas no. 39 tahun 2009 menyebutkan bahwa ruang lingkup supervisi akademik meliputi:

1. membina guru dalam merencanakan, melaksanakan dan menilai proses pembelajaran 
2. memantau pelaksanaan standar isi

3. memantau pelaksanaan standar proses

4. memantau pelaksanaan standar kompetensi kelulusan

5. memantau pelaksanaan standar tenaga pendidik dan

6. memantau pelaksanaan standar penilaian.

Peningkatkan sumber daya guru yang berkualitas perlu dilakukan secara terprogram, terstruktur dan berkelanjutan melalui pembinaan profesional yang dilakukan oleh kepala sekolah selaku manajer sumber daya manusia. Melalui supervisi akademik kepala sekolah mampu menampung berbagai masalah yang dihadapi oleh guru dalam proses pembelajaran untuk dapat menemukan cara-cara pemecahan permasalahan. Esensi supervisi akademik adalah membantu guru mengembangkan kemampuan profesionalismenya. Hal ini juga dilakukan oleh kepala sekolah SD Laboratorium UKSW dalam pemecahan masalah yang berkaitan dengan administrasi penilaian pembelajaran dimana ada sebagian guru di SD Laboratorium UKSW yang belum kompeten dalam menyusun administrasi penilaian pembelajaran dengan baik

\section{Prinsip Supervisi Pendidikan}

Dalam melaksanakan tugasnya seorang supervisor harus berpegang pada prinsip-prinsip yang kokoh demi kesuksesan tugasnya atau memiliki pedoman bagi pelaksnaan tugasnya, yaitu:

1. Prinsip Fundamental/ dasar (Foundamental/ basic principle)

Setiap pemikiran, sikap dan tindakan seorang supervisor harus berdasar/ berlandaskan sesuatu yang kokoh/ kuat serta dapat dipulangkan kepadanya. Bagi bangsa indonesia Pancasila adalah falsafah dan dasar negara kita, sehingga bagi supervisor, Pancasila adalah prinsip fundamental. Setiap supervisor pendidikan Indonesia harus bersikap konsisten dan konsekuen dalam pengamalan sila-sila Pancasila secara murni dan konsekuen.

\section{Prinsip Praktis}

Sesuai prinsip fundamental sebagai pedoman seorang supervisor pendidikan Indonesia, maka dalam pelaksanakan sehari-hari mereka berpedoman pada prinsip positif dan prinsip negatif.

a) Prinsip positif merupakan pedoman yang harus dilakukan seorang supervisor agar berhasil dalam pembinaannya.

- Supervisi harus konstruktif dan kreatif Supervisi harus mampu membangun pendidikan dan pengajarn ke arah yang lebih baik dengan mengembangkan aktivitas, daya kreasi dan inisitaif orang-orang yang disupervisinya.

- Supervisi harus dilakukan berdasarkan hubungan profesional, bukan berdasarkan hubungan pribadi/ konco.

- Supervisi hendaklah progresif tekun, sabar, tabah dan tawakal.
- Supervisi hendaklah dapat mengembangkan potensi, bakat dan kesanggupan untuk mencapai kemajuan.

- Supervisi hendaklah senantiasa memperhatikan kesejahteraan serta hubungan baik yang dinamik.

- $\quad$ Supervisi hendaklah bertolak dari keadaan yang kini nyata ada (Das Sein) menuju sesuatu yang dicitacitakan (Das Sollen).

- Supervisi harus jujur, objektif dan siap mengevaluasi diri sendiri demi kemajuan.

b) Prinsip negatif merupakan pedoman yang tidak boleh dilakukan oleh seorang supervisorr dalam pelaksanakan supervisi.

- Supervisi tidak boleh memaksakan kemauannya (otoriter) kepada orang-orang yang disupervisi. Berikan argumentasi/ alasan yang rasional tentang tindakan-tindakan serta instruksi-instruksinya. Jangan menonjolkan jabatan/ kekuasaannya agar tidak menghambat kreativitas bawahannya.

- Supervisi tidak boleh dilakukan berdasarkan hubungan pribadi, keluarga, persahabat-an dan sebagainya.

- Supervisi hendaklah tidak menutup kemungkinan terhadap perkembangan dan hasrat untuk maju bagi bawwahannya dengan dalih apapun. Supervisi tidak boleh terlalu cepat mengharapkan hasil, mendesak dan memperkuda bawahan.

- Supervisi tidak boleh menutup kemungkinan terhadap hasrat berkembang dan ingin maju dari bawahannya dengan segala dalih apapun.

- Supervisi tidak boleh mengeksploitasi bawahan dan bersifat otoriter.

- Supervisi tidak boleh menuntut prestasi diluar kemampuan bawahannya/ cita-cita muluk-muluk yang hampa.

- Supervisi tidak boleh egois. Tidak jujur dan menutup diri terhadap kritik dan saran dari bawahannya.

\section{Peranan Supervisi Pendidikan}

\section{Peran Supervisor}

Pembinaan profesional dilakukan karena satu alasan, yaitu memberdayakan akuntabilitas profesional guru yang pada gilirannya meningkatkan mutu proses dan hasilpembelajaran. Untuk maksud tersebut, para supervisor hendaknya melakukan peranansebagai berikut:

\section{1). Peneliti.}

Seorang supervisor dituntut untuk mengenal dan memahami masalah-masalahpengajaran. Karena itu ia perlu mengidentifikasi masalah-masalah pengajaran kjdan mempelajari faktor-faktor atau sebab-sebab yang mempengaruhinya.

2) Konsultan atau Penasihat.

Seorang supervisor hendaknya dapat membantu guruuntuk melakukan cara-cara yang lebih baik dalam 
mengelola proses pembelajaran. Oleh sebab itu, para pengawas hendaknya selalu mengikuti perkembangan masalah-masalahdan gagasan-gagasan pendidikan dan pengajaran mutakhir. Ia dituntut untuk banyakmembaca dan menghadiri pertemuan-pertemuan profesional, sehingga ia memilikikesempatan untuk saling tukar informasi tentang masalah-masalah pendidikan danpengajaran yang relevan, yaitu gagasan-gagasan baru mengenai teori dan praktikpengajaran.

\section{3) Fasilitator.}

Seorang supervisor harus mengusahakan agar sumber-sumberprofesional, baik materi seperti buku dan alat pelajaran maupun sumber manusia yaitunarasumber mudah diperoleh guru-guru. Dengan perkataan lain, hendaknya supervisordapat menyediakan kemudahan-kemudahan bagi guru dalam melaksanakan tugasprofesionalnya.

\section{4) Motivator.}

Seorang supervisor hendaknya membangkitkan dan memeliharakegairahan kerja guru untuk mencapai prestasi kerja yang semakin baik. Guru-gurudidorong untuk mempraktikkan gagasan-gagasan baru yang dianggap baik bagipenyempurnaan proses pembelajaran, bekerjasama dengan guru (individu ataukelompok) untuk mewujudkan perubahan yang dikehendaki, merangsang lahirnya idebaru, dan menyediakan rangsangan yang memungkinkan usaha-usaha pembaruan dapatdilaksanakan dengan sebaik-baiknya.

\section{4) Pelopor Pembaharuan.}

Para supervisor jangan merasa puas dengan caracaradan hasil yang sudah dicapai. Pengawas harus memiliki prakarsa untuk melakukanperbaikan, agar gurupun melakukan hal serupa. Pengawas sekolah tidak bolehmembiarkan guru mengalami kejenuhan dalam pekerjaannya, karena mengajar adalahpekerjaan dinamis. Guru-guru perlu dibantu untuk menguasai kecakapan baru, untuk itupara supervisor harus menyusun program latihan dan pengembangan dengan caramerencanakan pertemuan atau penataran sesuai dengan kebutuhan. Kualitas kelas danPBM sangat berhubungan dengan upaya pembinaan yang dilakukan secara terus menerustentunya dilakukan bersama antara gur itu sendiri, kepala sekolah dan pengawas sekolah.

\section{Perilaku Supervisor}

Perilaku supervisor tergantung pada pemahamannya mengenai tujuan pembinaanprofesional. Jika dianalisis, tingkat kualitas perilaku pembinaan berwujud:
* Memperhatikan

* mengerti atau memahami

* membantu dan membimbing

* memupuk evaluasi diri bagi perbaikan dan pengembangan

* memupuk kepercayaan diri

* memupuk, mendorong bagi pengembangan inisiatif

* kreativitas, dan pertumbuhan diri secara profesional. Supervisor diharapkan memiliki perilaku pembinaan profesionalnya pada tingkat tertinggi.

\section{KESIMPULAN}

Seorang supervisor dapat menggunakan berbagai alat bantu. Alat-alat bantu itu dipergunakan dengan maksud untuk memungkinkan pertumbuhan kecakapan dan perkembangan penguasaan pengetahuan oleh guru/ orang yang disupervisi sesuai dengan perkembangan ilmu pengetahuan pada umumnya dan ilmu pendidikan khususnya. Manfaat akhir dari proses supervisi adalah suatu hal yang tidak mudah dalam sistem manajemen personalia diIndonesia, seperti untuk melakukan mutasi, demosi, apalagi pemecatan petugas sekolah yang tidak becus. Begitu pula halnya dengan perubahan kurikulum yang sangat bersifat sentralisasi yang kurang memperlihatkan perbedaan masing-masing sekolah. Namun demikian apapun halangannya kegiatan supervisi harus tetap dilaksanakan, walaupun hanya sampai pada batas yang sangat bersahaja.

\section{Daftar Pustaka}

Afriansyah, H. (2019). Administrasi Peserta Didik. Padang. https://doi.org/10.17605/OSF.IO/NRXH8

Astuti, Suhandi. Januari 2017.Supervisi Akademin Untuk Meningkatkan Kompetensi Guru. Scholaria, Vol. 7 No 1,: 49 59.

Bakar, Abu. 2011. Supervisi Pendidikan Agama Islam. Jurnal Sosial Budaya, Vol. 8 No. 01

Suryani, Cut. 2015. Jurnal Ilmiah Implementasi Supervisi Pendidikan. VOL. 16, NO. 1, 23-42.

Zainuddin. 2018.. Jurnal Serambi Ilmu, Volume 30, Nomor 2, hal : 154 